\title{
KAJIAN PENGARUH VARIASI TEMPERATUR TERHADAP STRUKTUR KRISTAL BERBAGAI LAPISAN KOMPOSIT NIKEL
}

\author{
Diah Kartika Rahman ${ }^{1)}$, Esmar Budi ${ }^{2)}$, Hadi Nasbey ${ }^{1)}$ \\ ${ }^{1}$ Program Studi Fisika Universitas Negeri Jakarta, Indonesia \\ ${ }^{2}$ Program Studi Pendidikan Fisika Universitas Negeri Jakarta, Indonesia \\ Email: a)akartikarahman@gmail.com
}

\begin{abstract}
Abstrak
Kehidupan manusia tidak terlepas dari kebutuhan akan logam salah satunya untuk peralatan perkakas. Material yang memiliki sifat kekerasan yang baik dan bisa diaplikasikan sebagai alat perkakas seperti mata bor, yaitu komposit. Salah satu metode pembentukan lapisan komposit yang relatif murah dan mudah adalah elektrodeposisi. Pada tulisan ini telah dikaji hasil pengujian beberapa lapisan komposit dengan matriks nikel $(\mathrm{Ni})$ yang dibentuk menggunakan metode elektrodeposisi dan dikarakterisasi dengan XRD. Salah satu kondisi yang mempengaruhi struktur kristal lapisan komposit adalah temperatur, hal ini dibuktikan dengan hasil karakterisasi XRD dimana terlihat penurunan ukuran kristal dan peningkatan parameter kisi pada saat temperatur meningkat.
\end{abstract}

Kata-kata kunci: Elektrodeposisi, Lapisan komposit, temperatur.

\begin{abstract}
Human life is inseparable from the need for metal, one of which is for tooling equipment. Materials that have good hardness properties and can be applied as tool tools such as drill bits, namely composites. One of the relatively inexpensive and easy methods of forming composite layers is electrodeposition. In this paper, the results of testing of several composite layers with a nickel (Ni) matrix were formed using the electrodeposition method and were characterized by XRD. One of the conditions that affect the crystal structure of the composite layer is temperature, this is evidenced by the results of XRD characterization which shows a decrease in crystal size and an increase in lattice parameters when the temperature increases.
\end{abstract}

Keywords: Electrodeposition, composite coating, temperature.

\section{PENDAHULUAN}

Kemajuan teknologi di bidang material berkembang seiring dengan kebutuhan manusia. Kehidupan manusia tidak terlepas dari kebutuhan akan logam salah satunya untuk peralatan perkakas. Perkembangan material didukung oleh beberapa faktor salah satunya, yaitu teknologi material. Setiap material memiliki karakteristik yang berbeda-beda. Oleh karena itu, tuntutan penggunaan material harus diimbangi dengan pengetahuan terhadap karakteristik material yang akan digunakan. 
Karakteristik dari suatu material yang penting untuk ditinjau agar memperoleh material yang tepat adalah sifat kekerasan dari material tersebut. Material yang memiliki sifat kekerasan yang baik dan bisa diaplikasikan sebagai alat perkakas seperti mata bor, yaitu komposit. Komposit merupakan suatu struktur yang tersusun atas beberapa bahan pembentuk tunggal yang digabungkan menjadi struktur baru dengan sifat yang lebih baik dibadingkan dengan masing-masing bahan pembentuknya [22].

Jenis komposit yang banyak digunakan dalam aplikasi industri khususnya di bidang otomotif, elektronik, dan bidang produksi energi adalah Metal matrix composite (MMC). MMC memiliki keungguluan diantaranya dapat meningkatan ketahanan aus, koefisien gesekan rendah, dan meningkatkan ketahanan terhadap suhu tinggi dan ketahanan korosi [11]. Metode untuk meningkatkan sifat mekanis pada material yaitu dengan proses pelapisan komposit pada permukaan material. Lapisan digunakan sebagai bahan pelindung terhadap keausan dan anti korosi serta meningkatkan kekerasan.

Salah satu metode pembentukan lampisan komposit yang sedang berkembang pesat adalah elektrodeposisi. Elektrodeposisi adalah suatu proses pembentukan endapan logam pada katoda menggunakan energi listrik melalui suatu elektrolit [7]. Kelebihan dari metode elektrodeposisi antara lain membutuhkan biaya operasi yang relatif murah, memungkinkan untuk mengatur ketebalan lapisan dengan mudah, prosesnya yang sederhana, serta memungkinkan untuk membuat lapisan permukaan yang lebih luas [20].

Dalam proses pelapisan, kondisi yang harus diperhatikan karena menentukan tingkat keberhasilan proses pelapisan serta mutu yang diinginkan adalah temperatur [17]. Meningkatnya temperatur menyebabkan peningkatan ketebalan lapisan. Ini terjadi karena semakin meningkatnya temperatur mengakibatkan peningkatan energi yang akan mempercepat pelepasan ion elektron. Kondisi ini semakin mempercepat gerakan elektron dari anoda ke katoda sehingga yang mengendap di permukaan bahan semakin bertambah [23].

Tulisan ini merupakan kajian dari hasil pengujian beberapa lapisan komposit dengan matriks nikel (Ni) yang dibentuk menggunakan metode elektrodeposisi kemudian dikarakterisasi dengan X-Ray Difraction (XRD) untuk mengetahui pengaruh variasi temperatur terhadap struktur kristal dari lapisan tersebut.

\section{HASIL DAN PEMBAHASAN}

Komposit adalah kombinasi antara dua atau lebih dari tiga bahan yang memiliki sejumlah sifat yang tidak dimiliki oleh masing-masing komponennya. Dengan mengkombinasikan bahan tertentu maka akan diperoleh suatu sifat yang dikendaki. Bahan komposit biasanya dibangun dari dua fase yaitu fase matriks yang berfungsi sebagai bagian penutup dan pengikat struktur komposit dan fase dispersi (penambah) /reinforcement yang sifat materialnya memiliki kekuatan dan modulus elastisitas yang tinggi.

Ni (Nikel) adalah kelompok VIII elemen dari tabel periodik mempunyai nomor dan berat atom 28. Material logam yang biasa digunakan sebagai matriks pada proses elektrodeposisi salah satunya adalah Nikel [19]. Nikel (Ni) mempunyai kemampuan untuk berdeformasi tanpa menjadi patah. Pada pembentukan lapisan komposit, matriks membutuhkan bahan penguat yang bisa diisi dari kelompok Oksida, Karbida, Nitrida, Sulfida dan Silikon Nitrida. Dibawah ini adalah beberapa penelitian mengenai pengaruh temperatur terhadap sruktur kristal lapisan komposit.

TABEL 1. Penelitian-penelitian mengenai pengaruh temperatur terhadap sruktur kristal lapisan komposit.

\begin{tabular}{lllll}
\hline Penelitian & Tahun & Lapisan Komposit & Temperatur (oC) & Pengujian \\
\hline$[5]$ & 2018 & $\mathrm{Ni}-\mathrm{TiAlN} / \mathrm{Si} 3 \mathrm{~N} 4$ & 60 & $\mathrm{XRD}$ \\
{$[2]$} & 2018 & $\mathrm{Ni}(\mathrm{OH}) 2$ & $5,10,15,20,25$ & XRD \\
{$[9]$} & $\mathrm{Ni}$ & $20,50,80$ & XRD \\
{$[18]$} & 2016 & $\mathrm{Cu} / \mathrm{Ni}$ & 60 & $\mathrm{XRD}$ \\
{$[8]$} & 2017 & $\mathrm{Ni}-\mathrm{TiN}$ & 50 & $\mathrm{XRD}$ \\
\hline
\end{tabular}

Berdasarkan hasil karakterisasi lapisan komposit Ni-TiAlN/Si3N4 pada table diatas [5], diperoleh pola spektrum XRD dari lapisan komposit Ni-TiAlN/Si3N4, intensitas puncak tertinggi pada $2 \theta=$ 
31.50 dan $2 \theta=48.30$ masing-masing dimiliki oleh AlN (010) dan AlN (012), sedangkan puncak pada $2 \theta=35,60$ dimiliki oleh TiN (111). Puncak yang lebih rendah pada $2 \theta=44,60$ dimiliki oleh Ni (111).

Secara umum, dimungkinkan untuk melihat penurunan ukuran kristal dan peningkatan parameter kisi pada saat suhu meningkat. Berdasarkan hasil karakerisasi lapisan komposit $\mathrm{Ni}(\mathrm{OH}) 2$ pada tabel diatas [2], diketahui peningkatan dan penurunan parameter kisi dan ukuran kristal, masing-masing, dapat diamati dari 5 hingga $10{ }^{\circ} \mathrm{C}$. Selain itu, dari 10 hingga $25{ }^{\circ} \mathrm{C}$ didapatkan perubahan yang bervariasi pada parameter kisi dan ukuran kristal.

Berdasarkan hasil karakterisasi lapisan komposit Ni pada tabel diatas [9] diketahui bahwa Nikel murni nanokristalin yang diperoleh pada $20{ }^{\circ} \mathrm{C}$ berkembang sepanjang bidang kristal (111), sedangkan sampel yang diperoleh pada $50{ }^{\circ} \mathrm{C}$ berkembang sepanjang bidang kristal (200). Ukuran kristal dihitung dengan menggunakan formula Scherrer menunjukkan bahwa ukuran kristal deposit Ni pada $20{ }^{\circ} \mathrm{C}, 50{ }^{\circ} \mathrm{C}$, dan $80{ }^{\circ} \mathrm{C}$ masing-masing adalah $70 \mathrm{~nm}, 66 \mathrm{~nm}$ dan $62 \mathrm{~nm}$. Ukuran kristal nikel murni nanokristalin dipengaruhi secara signifikan oleh suhu larutan elektrodeposisi.

Berdasarkan hasil karakterisasi lapisan komposit $\mathrm{Cu} / \mathrm{Ni}$ pada tabel diatas [18], diperoleh semua sampel mengandung fasa $\mathrm{Cu}, \mathrm{Ni}$, dan $\mathrm{NiO}$ yang berstruktur kristal, sedangkan $\mathrm{CuO}$ berstruktur amorf. Puncak dominan $\mathrm{Cu}$ berada pada sudut difraksi $2 \theta$ sekitar $42^{\circ}$ dengan orientasi bidang hkl (111), sedangkan puncak dominan Ni terjadi pada sudut difraksi sekitar $39^{\circ}$ dengan orientasi bidang hkl (111). Fasa $\mathrm{NiO}$ muncul pada sudut $41,5^{\circ}$ dengan orientasi bidang hkl (111), sementara fasa $\mathrm{CuO}$ tidak ditemukan.

Berdasarkan hasil karakterisasi lapisan komposit Ni-TiN pada table diatas [8], diperoleh pola XRD lapisan nikel murni, menunjukkan tiga puncak intensitas yang berbeda, karakteristik struktur fcc dengan intensitas puncak tertinggi terdapat pada bidang kristal (220), sedangkan pola XRD lapisan nikel yang diendapkan dengan partikel TiN diperoleh peningkatan yang signifikan dalam intensitas puncak bidang kristal (111) dan (200).

\section{SIMPULAN}

Dari hasil beberapa penelitian diatas dapat disimpulkan bahwa lapisan komposit nikel dapat dibentuk menggunakan metode elektrodeposisi ditandai dengan terbentuknya kristal untuk fasa-fasa lapisan komposit. Faktor temperatur pada proses elektrodeposisi sangat mempengaruhi struktur kristal lapisan komposit dimana dimungkinkan untuk melihat penurunan ukuran kristal dan peningkatan parameter kisi pada saat temperatur meningkat.

\section{UCAPAN TERIMAKASIH}

Ucapan terima kasih ditujukan kepada semua pihak yang telah membantu dalam penelitian ini, yaitu Bapak Esmar Budi dan Bapak Hadi Nasbey selaku pembimbing dari Program Studi Fisika UNJ, serta teman-teman Fisika Murni UNJ 2016.

\section{REFERENSI}

[1] W. A. Andiani, E. Budi \& I. Sugihartono, "Pembentukan Lapisan Komposit Ni-Tialn/Si3n4 Menggunakan Metode Elektrodeposisi Dengan Variasi Temperatur," Prosiding Seminar Nasional Fisika, vol. 8, pp. 145-148, 2019.

[2] L. Aguilera \& Y. Leyet, "Influence Of Electrodeposition Temperature In The Electrochemical Properties Of $\mathrm{Ni}(\mathrm{Oh}) 2$ : An Experimental And Theoretical Study," Thin Solid Films, pp. 1-39, 2018.

[3] N. D. Anggraeni, "Analisa Sem (Scanning Electron Microscopy) Dalam Pemantauan Proses Oksidasi Magnetite Menjadi Hematite," Seminar Nasional - Vii Rekayasa Dan Aplikasi Teknik Mesin Di Industri Kampus Itenas - Bandung, 2008. 
[4] E. Budi, "Potensi Pembentukan Lapisan Super Dan Ultra Keras Senyawa Komposit Nitrida Menggunakan Kaidah Elektrodeposisi," Spektra: Jurnal Fisika Dan Aplikasinya, vol. 1, no. 2, p. 187, 2016.

[5] E. Budi et al., "Formation Of Electrodeposited Ni-Tialn/Si3n4 Composite," 3rd Annual Applied Science And Engineering Conference (Aasec ), pp. 1-5, 2018.

[6] A. Fikry, "Deposisi Lapisan Komposit Ni-Tialn/Si3n4 Menggunakan Metode Elektrodeposisi Dengan Variasi Konsentrasi Si3n4,” Jakarta: Universitas Negeri Jakarta.

[7] S. E. Huriyati, A. Haris \& D. S. Wido, "Kualitas Dan Mortologi Hasil Elektrodeposisi Kobal Pada Substrat Tembaga Teriiadap Pengaruh Rapat Arus Dan Asam Borat," Jurnal Sains \& Matematika, pp. 63-67, 2010.

[8] M. Ibrahim, F. Kooli \& S. N. Alamri, "Electrodeposition And Characterization Of NickelTin,” International Journal Of Electrochemical Science, pp. 12308-2320, 2013.

[9] L. Jinlong, L. Tongxiang \& W. Chen, "Effect Of Electrodeposition Temperature On Grain Orientation And Corrosion Resistance Of Nanocrystalline Pure Nickel," Journal Of Solid State Chemistry, pp. 1-18, 2016.

[10] K. Kornaus et al., "Mechanical And Thermal Properties Of Tungsten Carbide - Graphite Nanoparticles Nanocomposites," Polish Journal Of Chemical Technology, pp. 84-88, 2016.

[11] M. Lekka, "Electrochemical Deposition Of Composite Coatings," Udine: Elsevier Inc, 2018.

[12] S. Marwati, "Pengaruh Agen Pereduksi Dalam Proses Elektrodeposisi Terhadap Kualitas Deposit Cu Dan Ag," Prosiding Seminar Nasional Penelitian, Pendidikan Dan Penerapan Mipa, pp. 1-8, 2013.

[13] Muarief, E. Budi \& I. Sugihartono, "Sintesis Lapisan Tipis Komposit Ni-Tialn Menggunakan Teknik Elektrodeposisi Pada Berbagai Substrat," Prosiding Seminar Nasional Fisika (EJournal) Snf2015, pp. 81-84, 2015.

[14] H. S. Pakpahan, A. K. Wardani \& R. Ma, "Karakterisasi Bahan Konduktor (Besi, Baja, Dan Timbal) Dan Semikonduktor (Tungsten) Berdasarkan Percobaan Efek Hall," Bandung: Prosiding Simposium Nasional Inovasi Dan Pembelajaran Sains, 2015.

[15] T. S. Permana \& U. Rumendi, "Analisa Uji Keausan Material St 37 Hasil Carburizing Dan Hardening Dengan Menggunakan Mesin Uji Keausan Horizontal," Prosiding Seminar Nasional Teknologi Manufaktur 2014, pp. 1-5, 2018.

[16] Ridwan, "Variasi Konsentrasi Ion Ni2+ Terhadap Dispersi Si3n4 Pada Lapisan Nanokomposit Ni-Silikon Nitrit," Jurnal Sains Dan Teknologi, vol. 8, no. 2, 2016.

[17] Sugiyarta, A. P. Bayuseno \& S. Nugroho, "Pengaruh Konsentrasi Larutan Dan Kuat Arus Terhadap Ketebalan Pada Proses Pelapisan Nikel Untuk Baja Karbon Rendah Rotasi,” Jurnal Teknik Mesin, pp. 23-27, 2012.

[18] M. A. N. Toifur, Okimustava \& I. Sukarelawan, "Pengaruh Waktu Deposisi Pada Tebal Lapisan, Struktur Mikro, Resistivitas Keping Lapisan Tipis Cu/Ni Hasil Deposisi Dengan Teknik Elektroplating," Jurnal Material Dan Energi Indonesia, pp. 33-43, 2017.

[19] M. R. Vaezi, S. K. Sadrnezhaad \& L. Nikzad, "Electrodeposition Of Ni-Sic Nano-Composite Coatings And Evaluation Of Wear And Corrosion Resistance And Electroplating Characteristics," Colloids And Surfaces A: Physicochem, pp. 176-182, 2008.

[20] M. R. Wahidiyah et al., "Preparasi Lapisan Tipis Zno Dengan Metode Elektrodeposisi Untuk Aplikasi Dye-Sensitized Solar Cell (Dssc)," Jurnal Teknik Pomits, pp. 1-6, 2015. 
[21] N. Wahyuni \& M. Adnan, "Ketahanan Aus Dan Kekerasan Komposit Matrik Alumunium (Amcs) Paduan Alumunium Al-Si Ditambah Penguat Sic Dengan Metode Stir Casting. Prosiding Seminar Hasil Penelitian,” pp. 201-210, 2016.

[22] H. Yudo \& S. Jatmiko, "Analisa Teknis Kekuatan Mekanis Material Komposit Berpenguat Serat Ampas Tebu (Baggase) Ditinjau Dari Kekuatan Tarik Dan Impak," Semarang: Universitas Diponegoro.

[23] S. R. Yulianto, "Analisa Pengaruh Variasi Temperatur Proses Pelapisan Nikel Khrom Terhadap Kualitas Ketebalan Dan Kekerasan Pada Baja St 40," Proceeding Call For PaperSnft Umsida 2013, 145-149, 2013. 
